УДК 623.1/.7:007.52 (477)

\title{
METHODOLOGICAL AND SCIENTIFIC APPROACH INTO THE PROCESS OF CALCULATION A MULTILAYER UNDERGROUND PROTECTIVE STRUCTURE
}

\author{
V.I. Kotsyuruba, \\ Doctor of Technical Science, Professor, Honored Inventor of Ukraine \\ I.P. Datsenko, \\ Candidate of Technical Science \\ V.O. Dachkovsky, \\ Candidate of Technical Science \\ R.M. Cherevko, \\ Philosophy Doctor \\ O.V. Androshchuk, \\ Candidate of Psychology Science \\ A.L. Tsybizov, \\ Candidate of Military Science \\ V.I. Kryvtsun, \\ Candidate of Technical Science \\ The National Defense University of Ukraine named after Ivan Chernyakhovsky, 28,
Povitroflotskiy avenu, Kyiv, Ukraine
}

DOI: $10.32347 / 2410-2547.2021 .107 .159-169$

\begin{abstract}
During the Joint Forces (anti-terrorist operation) operation in Donetsk and Luhansk oblasts, civilians and the Armed Forces suffered significanted losses.

As a result, we have needed to study impact various weapons on structure roof of buildings which built of different materials to improve protective properties is becoming relevant.

Therefore, in modern conditions, design of structures and their elements is not possible without taking into account impact of shells. When designing and constructing structures, it is always necessary to take into account resistance of structural elements to impact of damaging factors, both explosion in general and destructive explosion in particular, which will help avoid future possible human losses.

The article presents model of calculation shell penetration into soil thickness covered shelter, consisting of scattering, mattress, distribution layer, load-bearing structure and impact of shells, mines and air bombs to penetrate the thickness of closed structures.

The purpose article is to highlight main provisions scientific and methodological approach to calculation multilayer underground protective structures and studies impact of projectiles on multilayer underground protective structure.

Our research shows that to determine protective thickness mattress of structure, during penetration of ammunition, first of all, should take into account resistance to scattering, and to determine thickness distribution layer resistance of mattress.

Depth of penetration projectile into thickness floor structure will depend on: mass, diameter, shape of main part projectile, as well speed and angle at meeting of projectile with the floor structure.
\end{abstract}

Key words: floor, protective structure, mattress, scattering, distribution layer, soil thickness, projectile, impact action.

(C) Kotsiuruba V.I., Datsenko I.P., Dachkovsky V.O., Cherevko R.M., Androshchuk O.V.,

Tsybizov A.L., Kryvtsun V.I. 
Introduction. Recently, issues of civil protection have become one of priority issues modern world. Ever-increasing threat terrorist acts and high probability military conflicts (as an example fighting in eastern Ukraine, which is supported by the Russian Federation) require a more detailed study security of buildings.

Unlike open structures (trenches, trenches, etc.), closed structures protect personnel and equipment from fire. Therefore, the roof structures are monolithic and multilayer (wood, soil, sand, metal), which assume the main impact and high-explosive action of striking elements warheads artillery shells, mortar mines and aerial bombs from the air [1-2].

During from construction structures, the obligatory element work is to determine the depth penetration warhead projectile material covered structures, puncture coating made of brittle materials, ricochet warhead projectile from the coating, as well as its destruction due to impact. These calculations are performed in order to determine the required level of security building during hostilities. According to results calculations, we obtain the required thickness coating layers (soil, sand, wood, wave steel, concrete, reinforced concrete, etc.).

One of mains materials for construction protective structures is concrete and reinforced concrete, which are an integral part of modern structures. According to building codes and regulations, structures are designed for totality all loads that can affect structure [3-4].

Analysis of research and publications has shown [5-8] that the study impact explosion on buildings is given sufficient attention. However, due to the rapid growth impact of modern means of destruction, existing scientific and methodological approaches need to be improved, as they do not fully take into account a number of important parameters, neglect of which leads to errors in calculations of protective coating thickness, probability it's punching or destruction, and, as a result, to the death of personnel and damage equipment.

The above necessitates a more in-depth study impact of projectile penetration into the depth protective structure to calculate the stability structures structure. Therefore, the aim article is to study the impact of projectiles on the multilayer underground protective structure.

The main material article. Protective structures are widespread in the general defense system of many states. First of all, due to high strength and durability of such structures [9].

In the modern development of weapons for various purposes, one main issues, which throughout development of mankind is essential, is effectiveness of certain structures, including directly concrete and reinforced concrete [10].

When the warhead projectile falls into the coating of buildings, it penetrates into its material to a certain depth and after spending energy to overcome the resistance of this material, it stops, this phenomenon is called penetration [1-2].

Therefore, when arranging a multilayer coating, it is necessary to determine the depth of penetration warhead projectile into the soil thickness. 
1. Calculation of shell penetration into the soil. The coating of layered structure consists of a scattering, mattress, distribution layer and bearing structure (Figure 1). There is no mattress in light type constructions [11].

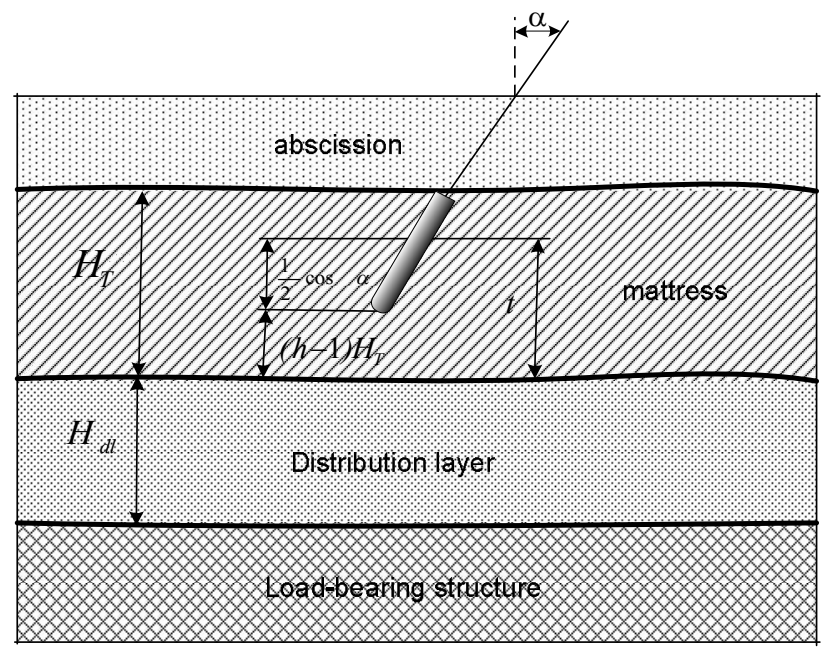

Fig. 1. Scheme for calculating coverage of layered structure

Sprinkling is used to mask structure and to reduce the spread of fragments when a projectile or air bomb explodes.

Smallest thickness of scattering is accepted $0,25-0,30 \mathrm{~m}$.

Mattress is designed to prevent the projectile from penetrating deep into protective layer and cause it to explode at a safe distance from the interior. If possible, the mattress should be made of such materials that have the best impact resistance to shells and air bombs masonry, beams or rails, stacked in rows, concrete, reinforced concrete, etc.). Thickness of the mattress is determined by Zabudskys formula:

$$
H_{T}=n h_{\text {pen }}^{T}
$$

where $n$ is the coefficient taken according to table 1 .

The value of the coefficient $n$

\begin{tabular}{|c|c|}
\hline Material & $n$ \\
\hline Soil & 1.5 \\
\hline Tree & 1.3 \\
\hline Reinforced concrete with flexible anti-splinter reinforcement & 1.7 \\
\hline Reinforced concrete with rigid anti-splinter reinforcement & 1.5 \\
\hline Reinforced concrete slab on the ground & 1.25 \\
\hline Mattress made of concrete or masonry & 1.4 \\
\hline
\end{tabular}


If Thickness of mattress is taken into account when determining thickness of mattress against impact, value $n h_{p e n}$. should be reduced by a value equivalent to the resistance scattering; thickness of mattress in this case is determined by the formula:

$$
H_{T}=n h_{\text {pen. }}^{T}-H_{0} \frac{K_{p e n .}^{T} .}{K_{p e n .}^{0} .}
$$

Distribution layer is made of sand or local soil. It is designed to weaken action of blast wave. Thickness of distribution layer must be such that the load-bearing structure is not damaged during explosion. This requires that the load-bearing structure does not fall into the sphere of destruction.

It should be borne in mind that if projectile explodes in mattress, then part of explosive action is perceived by mattress material, so when determining thickness of distribution layer, it is necessary to subtract from radius of fracture sphere calculated for material of distribution layer.

$$
H_{p c}=r_{r}^{p c}-t \frac{K_{r}^{p c}}{K_{r}^{T}},
$$

where $t$ - is thickness of mattress below the center of charge, ie distance from center of charge to bottom of mattress.

The value of $t$, as can be seen from drawing, is equal to:

$$
t=(n-1) H_{T}+\frac{1}{2} \cos \alpha,
$$

where $n$-is the coefficient in Zabudskys formula.

The coating of layered structure can be arranged without a mattress, with soil or stone scattering, which protects against penetrating radiation, mines, and sometimes whole shells, and with a load-bearing structure in the form of a continuous row of logs, corrugated steel, reinforced concrete elements, etc. The coating, calculated on action of fragmentation mines, equipped with detonators of instantaneous action, must have a thickness of scattering, which is determined by the formula:

$$
H_{0}=r_{r}^{0}-d=K_{r} \sqrt[3]{C}-\frac{1}{2} \cos \alpha,
$$

where $r_{r}^{0}-$ is the radius of sphere destruction in scattering material; $K_{r}-$ coefficient of susceptibility to destruction scattering material; $C$ - weight of mine charge in $\mathrm{kg} ; \frac{1}{2}$ - half-length mine without a stabilizer; $\alpha$ - meeting angle.

The coating, calculated on combined effect of impact and explosion of shells or high-explosive minutes, must have a scattering, thickness of which is determined by the formula:

$$
H_{0}=h_{\text {pen. }}+m K_{r} \sqrt[3]{C}-d
$$

where $m$ - clogging ratio; $d=\frac{1}{2} \cos \alpha ; l$ - projectile length (mines); $K_{r}-$ coefficient susceptibility destruction of scattering material. 
Such coatings require a large deepening of structure into the ground, and therefore in many cases their use is impractical.

Protection hull of recessed structures on sides, is possible due to the fact, that mattress is arranged wider than structure itself, so that projectile penetrating the edge of mattress, exploded at a safe distance from hull. Mattress must intercept the shells without letting them into dangerous places for construction.

Mattress removal, or distance in horizontal direction from edge of frame to edge of mattress (Figure 2), is determined by the formula:

$$
B=R_{\text {safe }}+Z,
$$

where $R_{\text {safe }}$ - smallest distance between center of charge and hull (wall) at which explosion will be safe for construction; this distance is called safe break distance, or safe radius; $Z$ - horizontal projection of projectile path under the mattress.

The safety gap distance $R_{\text {safe }}$ is usually determined without taking into account strength of wall by formula:

$$
R_{\text {safe }=r_{r}}=m K_{r} \sqrt[3]{C},
$$

where $m$ - clogging ratio; $K_{r}-$ coefficient of susceptibility soil to destruction; $C$ - charge weight in $\mathrm{kg}$.

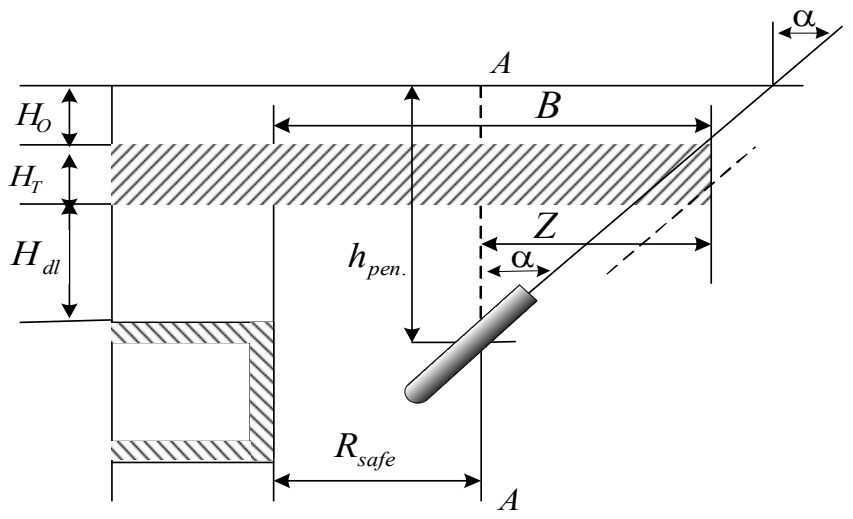

Fig. 2. Scheme for determining the removal of the mattress

The removal mattress is most convenient determine graphically, after some calculations.

After calculating distance safe gap, postpone scale of its value in horizontal direction from the wall of structure. A vertical line $A$ is drawn through the obtained point. This line marks boundary beyond which projectile (charge center) cannot be allowed. Then, realizing the depth penetration of projectile into the ground put it on a scale from the ground down. From obtained point (a) draw a line at angle meeting $a$. This line will be extreme trajectory 
projectile, which must be intercepted by a mattress. The end of mattress is carried out as shown in Figure 2.

The removal mattress can also be determined by formula:

$$
B=\left(h_{\text {pen. }}^{\text {gr. }}-H_{0}-H_{T}\right) \operatorname{tg} \alpha+R_{\text {safe }},
$$

where $B$ - mattress removal; $H_{0}$ - scattering thickness; $H_{T}$ - mattress thickness; $\alpha$ - angle projectile; $R_{\text {safe }}-$ safe radius.

The removal mattress towards flanks of structure is equal to $0.6-0.7$ of amount removal mattress towards the enemy. The removal mattress rear is determined by the condition of protecting rear wall from howitzer shells or air bombs.

To protect the walls from air bombs, mattress is usually arranged horizontally. To protect against shells, mattress can be arranged in a broken pattern.

2. Calculation impact of shells mines and air bombs on penetration into the thickness floor of closed fortifications. In contrast of open, the closed fortifications, of their overlap, protect personnel, weapons and military equipment and logistics from artillery fire, which is especially important troops conducting hostilities at advanced positions [12].

The point of calculation impact artillery shells, mortar mines and aircraft bombs (hereinafter - shells) on penetration into thickness floor closed fortifications is that the projectile at time meeting with the floor rotates around its axis. As a result, the projectile penetrates deeper into the floor of fortification structure, which increases efficiency its destruction by the explosion of explosive charge projectile and inflicts damage on personnel and equipment in the fortifications.

Under these conditions, there is a need to calculate the depth of penetration projectile into the floor fortification structure in order to create such a thickness that will withstand the explosion projectile and protect personnel and equipment.

According to [13] the depth of penetration projectile into the thickness fortification structure depends shape of the main part projectile, the mass projectile, its diameter, the velocity projectile at the time of its encounter with the fortification structure, buildings. This value is determined by the following formula:

$$
h_{\text {pen. }}=\lambda k_{\text {pen. }} \frac{P}{d^{2}} V \cos \alpha,
$$

where $\lambda$ - coefficient that depends on the shape main part projectile; $k_{p e n}$. the coefficient of pliability floor material; $P$ - projectile weight, $\mathrm{kg} ; d-$ projectile diameter, $\mathrm{m} ; V$ - projectile velocity at the time of meeting with the floor, $\mathrm{m} / \mathrm{s} ; \alpha$ - the angle projectile with the floor.

Value $\alpha$ depends on the slope floor surface fortification structure and the angle of incidence projectile, or angle between the horizontal plane floor and the axis projectile at point of their meeting. 
Thus, if the floor surface fortification is horizontal, the sum angles of encounter and fall is $90^{\circ}$ (Figure 3(a)). $3(b))$.

For a vertical surface, the meeting angle is equal angle of incidence (Figure

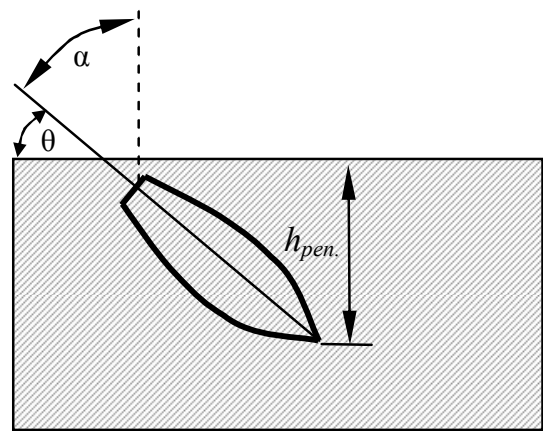

(a)

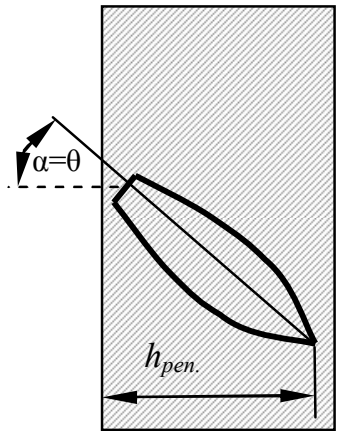

(b)

Fig. 3. Scheme of penetration projectile:

(a) into the horizontal barrier, (b) into the vertical barrier

If the projectile hits the floor fortification perpendicular to its surface, the direction of movement projectile in the floor does not change, ie remains straight. In this case, the meeting angle $\alpha=0^{\circ}, \cos \alpha=1$ and formula (10) takes the following form:

$$
h_{\text {pen. }}=\lambda K_{\text {pen. }} \frac{P}{d^{2}} V .
$$

If the projectile enters the protective layer fortification structure at some angle to its surface, the penetration into the floor due to the rotation projectile actually takes place not in a straight line but in a curved trajectory, which is directed with its convex side to the bottom (Figure 4).

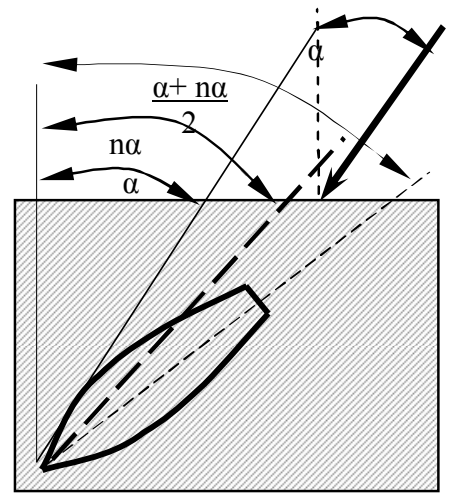

Fig. 4. Scheme penetration projectile into protective layer the fortification structure at an angle to its surface due to rotation of projectile 
Accordingly, the depth penetration of projectile into the floor of fortification structure in a curved trajectory will be less than the depth of penetration in a straight line. Therefore, if the projectile hits the floor of fortification at an angle of encounter $\alpha$, then at the end of such penetration, angle between axis of projectile and perpendicular to the obstacle surface will be greater than angle of encounter, for example, $n$ times, ie will be equal to $n \alpha$. Therefore, in formula (10) instead meeting angle $\alpha$, should be substituted the average value between $\alpha$ and $n \alpha$, which is equal to the half-sum of these angles. The formula (10) will take following form:

$$
h_{\text {pen. }}=\lambda K_{\text {pen. }} \frac{P}{d^{2}} V \cos \frac{\alpha+n a}{2} .
$$

The coefficient $n$ is called the coefficient of reversal of projectile, value of which in most cases is taken equal to one.

So, considering that the projectile penetrates into floor fortifications in a straight line, without reversal, its necessary to increase his thickness, which is a feature of calculation impact of shells, mines and bombs on penetration into the floor of closed fortifications.

Conclusions. Our research shows that when penetrating ammunition into the soil thickness to determine the thickness mattress against the impact action must take into account the scattering resistance, the value of $n h_{p e n}$. must be reduced by an amount equivalent to the scattering resistance. If the projectile explodes in the mattress, then part explosive action is perceived by the mattress material, so when determining the thickness distribution layer, it is necessary to subtract from the radius fracture sphere calculated for the distribution layer material the equivalent of explosive mattress resistance.

During the theoretical study impact of shells, mines and air bombs on the penetration floor of closed fortifications, it was determined that the depth of penetration projectile into the floor will depend on: the shape main part projectile, its mass, diameter, velocity with the overlap structure and the angle projectile with the overlap structure and the pliability material floor structure.

\section{REFERENCES}

1. Military fortifications. - Moscow: Military Publishing House, 1984. - 720 p. (in Russian).

2. Kushnirenko M.G., Vorovich B.O., Lisnevsky V.V. Building materials, structures and basics of mechanics of military engineering structures. Kyiv: NAOU, 2000. - 67 p. (in Ukraine).

3. Tuzikov S.A. Analysis of requirements for protective structures of civil defense and methodological approaches to their classification / S.A. Tuzikov, S.O. Kovzhoga, EV Pocket, AF Lazutsky, A.V. Pisarev / Collection of scientific works of HUPS. - 2013. - №1(34), P. 186-189. (in Ukraine).

4. Kobylkin I.F. Shock and detonation waves: Research methods / I.F. Kobylkin, V.V. Selivanov, V.S. Soloviev, N.N. Sysoev - Moscow: Fizmatlit, 2004. - 375 p. (in Russian).

5. Vasilchenko O.V. Building constructions and their behavior in the conditions of emergency situations: Textbook / O.V. Vasilchenko, Y.V. Kvitkovsky, O.A. Wheelman. - Kharkiv: KhNADU, 2015. - 488 p. (in Ukraine).

6. Mkrtychev O.V. Calculation of structures of a reinforced concrete building for explosive loads in a nonlinear dynamic setting / O.V. Mkrtychev, V.B. Dorozhinsky, O.V. Lazarev / Bulletin of MGSU. - 2011. - No.4, S. 243-247. (in Russian). 
7. Mukhin V.I., Rybakov A.V., Vildanov R.R. On a computational model for assessing the damaging effect of an air shock wave from conventional weapons. / Izvestiya of the Institute of Engineering Physics. - 2017. - №1, P. 58-63. (in Russian).

8. Kvitkovsky Yu.V. Determination of shock wave parameters formed during the explosion of a gas-air mixture. / Kvitkovsky Yu.V., Prokhach E.Yu. / Collection of scientific works of UCZU. - 2006. - №4, P.120-124. (in Ukraine).

9. Ananich S.A., Buznik P.K., Sukharev A.I. Fortification. Textbook of military engineering schools. - Moscow: 1964. 445 p. (in Russian).

10. Methodical recommendations of the order of the engineering equipment of positions of divisions of antiaircraft missile troops of air forces of ZSU / Ya.V. Biletsky, G.A Keith, W.L. Freebies. K.: KP ZSU. 2019. 167 p. (in Ukraine).

11. Ovcharenko V.A., Podlesny S.V., Zinchenko S.M. Fundamentals of the finite element method and its application in engineering calculations: an initial manual. - Kramatorsk: DSEA, 2008. - 380 p. (in Ukraine).

12. Vasilchenko V.P. Fortification equipment of positions and areas of deployment of troops: textbook. manual. Moscow: VIA, 1990.184 p. (in Russian).

13. Manual on military engineering: textbook. manual. Moscow: Military Publishing, 1984. 575 p. (in Russian).

Стаття надійшла 15.08.2021

Кочюруба В.І., Даченко І.П., Дачковський В.О., Черевко Р.М., Андрощук О.В., Цибізов А.Л., Кривиун B.I.

\section{НАУКОВО-МЕТОДИЧНИЙ ПІДХІД ЩОДО РОЗРАХУНКУ БАГАТОШАРОВОЇ ПІДЗЕМНОЇ ЗАХИСНОЇ СПОРУДИ}

За час ведення операції Об'єднаних сил (антитерористичної операції) на території Донецької та Луганської областей мирне населення та ЗСУ зазнали значних втрат.

Стає актуальним питання щодо необхідності вивчення впливу різноманітної зброї на конструкції покриття споруд, які побудовані з різних матеріалів для підвищення захисних властивостей.

Тому в сучасних умовах проектування споруд та їх елементів не можливе без урахування ударної дії снарядів. При проектуванні та будуванні споруд завжди потрібно враховувати стійкість елементів конструкцій до дії вражаючих факторів, як вибуху в цілому так і ударної хвилі вибуху зокрема, що допоможе уникнути майбутніх можливих людських втрат.

В статті представлено розрахунок проникнення снарядів в товщу грунту перекритого укриття, що складається з обсипання, тюфяка, розподільчого шару, несучої конструкції та ударної дії снарядів, мін і авіабомб на проникнення у товщу перекриття закритих споруд.

Метою статті є висвітлення основних положень науково-методичного підходу щодо розрахунку багатошарової підземної захисної споруди та досліджень впливу ударної дії снарядів на багатошарову підземну захисну споруду.

Проведене дослідження показує, що для визначення захисної товщини тюфяка споруди, під час проникнення боєприпасів, в першу чергу, слід враховувати опір обсипання, а для визначення товщини розподільного шару опір тюфяка.

Глибина проникнення снаряду у товщу перекриття споруди буде залежати від: маси, діаметру, форми головної частини снаряду, а також від швидкості руху та кута у момент зустрічі снаряда з перекриттям споруди.

Key words: перекриття, захисна споруда, тюфяк, обсипання, розподільчий шар, товща грунту, снаряд, ударна дія.

Kotsiuruba V.I., Datsenko I.P., Dachkovsky V.O., Cherevko R.M., Androshchuk O.V., Tsybizov A.L., Kryvtsun V.I.

METHODOLOGICAL AND SCIENTIFIC APPROACH INTO THE PROCESS OF CALCULATION A MULTILAYER UNDERGROUND PROTECTIVE STRUCTURE

During the Joint Forces (anti-terrorist operation) operation in Donetsk and Luhansk oblasts, civilians and the Armed Forces suffered significanted losses. 
As a result, we have needed to study impact various weapons on structure roof of buildings which built of different materials to improve protective properties is becoming relevant.

Therefore, in modern conditions, design of structures and their elements is not possible without taking into account impact of shells. When designing and constructing structures, it is always necessary to take into account resistance of structural elements to impact of damaging factors, both explosion in general and destructive explosion in particular, which will help avoid future possible human losses.

The article presents model of calculation shell penetration into soil thickness covered shelter, consisting of scattering, mattress, distribution layer, load-bearing structure and impact of shells, mines and air bombs to penetrate the thickness of closed structures.

The purpose article is to highlight main provisions scientific and methodological approach to calculation multilayer underground protective structures and studies impact of projectiles on multilayer underground protective structure.

Our research shows that to determine protective thickness mattress of structure, during penetration of ammunition, first of all, should take into account resistance to scattering, and to determine thickness distribution layer resistance of mattress.

Depth of penetration projectile into thickness floor structure will depend on: mass, diameter, shape of main part projectile, as well speed and angle at meeting of projectile with the floor structure.

Key words: floor, protective structure, mattress, scattering, distribution layer, soil thickness, projectile, impact action.

УДК 623.1/.7:007.52 (477)

Кочюруба В.І., Даченко І.П., Дачковський В.О., Черевко Р.М., Андрощук О.В., Цибізов А.Л., Кривиун B.I. Науково-методичний підхід щодо розрахунку багатошарової підземної захисної споруди // Опір матеріалів і теорія споруд: наук.-тех. збірн. - К.: КНУБА, 2021. Вип. 107. - С. 159-169.

В статті представлено розрахунок проникнення снарядів в товщу трунту перекритого укриття, що складається з обсипання, тюфяка, розподільчого шару, несучої конструкиії та ударної дії снарядів, мін і авіабомб на проникнення у товщу перекриття закритих споруд.

Бібл. 13, рис. 4 , табл. 1.

UDC 623.1/.7:007.52 (477)

Kotsiuruba V.I., Datsenko I.P., Dachkovsky V.O., Cherevko R.M., Androshchuk O.V., Tsybizov A.L., Kryvtsun V.I. Methodological and scientific approach into the process of calculation a multilayer underground protective structure // Strength of Materials and Theory of Structures: Scientific-andtechnical collected articles - Kyiv: KNUBA, 2021. - Issue 107. - P. 159-169.

The article presents model of calculation shell penetration into soil thickness covered shelter, consisting of scattering, mattress, distribution layer, load-bearing structure and impact of shells, mines and air bombs to penetrate the thickness of closed structures.

Ref. 13, Fig. 4, Tabl. 1.

Автор (вчена ступень, вчене звання, посада): доктор технічних наук, доцент, професор кафедри оперативного та бойового забезпечення Національного університету оборони України імені Івана Черняховського, КОЦЮРУБА Володимир Іванович

Адреса робоча: 03049, м. Київ, Повітрофлотський проспект, 28, Національний університет оборони України імені Івана Черняховського.

Робочий тел.: +38 044 271-06-97, факс +38 044 271-06-97 03680 .

Мобільний тел.: +38(050) 833-31-90,

E-mail: kotcuru@ukr.net

ORCID ID: https://orcid.org/ 0000-0001-6565-9576

Автор (вчена ступень, вчене звання, посада): кандидат технічних наук, начальник лабораторії Центру воєнно-стратегічних досліджень Національного університету оборони України імені Івана Черняховського, ДАЦЕНКО Іван Петрович 
Адреса робоча: 03049 , м. Київ, Повітрофлотський проспект, 28, Національний університет оборони України імені Івана Черняховського

Робочий тел.: +38 044 271-06-97, факс +38 044 271-06-97 03680

Мобільний тел.: +38(093) 475-31-67

E-mail: docik_ivan@i.ua

ORCID ID: https://orcid.org/0000-0002-0047-413X

Автор (вчена ступень, вчене звання, посада): кандидат технічних наук, доцент, доцент кафедри технічного забезпечення Національного університету оборони України імені Івана Черняховського, ДАЧКОВСЬКИЙ Володимир Олександрович

Адреса робоча: 03049 , м. Київ, Повітрофлотський проспект, 28, Національний університет оборони України імені Івана Черняховського.

Робочий тел.: +38 044 271-06-97, факс +38 044 271-06-97 03680.

Мобільний тел.: +38(067) 422-21-75,

E-mail: 1903vova@ukr.net

ORCID ID: https://orcid.org/ 0000-0003-1480-5021

Автор (вчена ступень, вчене звання, посада): доктор філософії, старший науковий співробітник Центру воєнно-стратегічних досліджень Національного університету оборони України імені Івана Черняховського, ЧЕРЕВКО Руслан Михайлович

Адреса робоча: 03049 , м. Київ, Повітрофлотський проспект, 28, Національний університет оборони України імені Івана Черняховського

Робочий тел.: +38 044 271-06-97, факс +38 044 271-06-97 03680

Мобільний тел.: +38(067) 841-04-44

E-mail: cherepruslan2017@gmail.com

ORCID ID: https://orcid.org/0000-0002-0047-413X

Автор (вчена ступень, вчене звання, посада): кандидат психологічних наук, науковий співробітник Центру воєнно-стратегічних досліджень Національного університету оборони України імені Івана Черняховського, АНДРОЩУК Ольга Володимирівна

Адреса робоча: 03049 , м. Київ, Повітрофлотський проспект, 28, Національний університет оборони України імені Івана Черняховського

Робочий тел.: +38 044 271-06-97, факс +38 044 271-06-97 03680

Мобільний тел.: +38(097) 964-44-71

E-mail: evilfate@ukr.net

ORCID ID: https://orcid.org/0000-0002-1032-7459

Автор (вчена ступень, вчене звання, посада): кандидат військових наук, старший науковий співробітник Центрального науково-дослідного інституту Збройних Сил України, ЦИБІЗОВ Андрій Леонідович

Адреса робоча: 03049, м.Киів, Повітрофлотський проспект,28, Центральний науководослідний інститут Збройних Сил України

Мобільний тел.: +38(096)3342814

E-mail: tsybizov@ukr.net

ORCID ID: https://orcid.org/0000-0001-6555-5005

Автор (вчена ступінь, звання, посада): кандидат технічних наук, старший науковий співробітник, начальник кафедри інженерної техніки факультет підготовки спеціалістів бойового (оперативного) забезпечення Національної академії сухопутних військ імені гетьмана Петра Сагайдачного, КРИВЦУН Володимир Іванович

Адреса робоча: 79026, м. Львів, вул. Героїв Майдану, 32, Національна академія сухопутних військ імені гетьмана Петра Сагайдачного.

Робочий телефон: +380 (32) 258-44-55

Мобільний тел.: +380 (67) 7561910

E-мail: vik-08-74@i.ua

ORCID ID: https://orcid.org/0000-0002-3907-5320 